\title{
Climate Trends of Temperature, Precipitation and River Discharge in the Abbay River Basin in Ethiopia
}

\author{
Asaminew Abiyu Cherinet1, Denghua Yan1,2,3*, Hao Wang1,2,3, Xinshan Song1, Tianlin Qin2,3, \\ Mulualem T. Kassa ${ }^{4}$, Abel Girma ${ }^{1,5}$, Batsuren Dorjsuren ${ }^{6}$, Mohammed Gedefaw ${ }^{1,5}$, Hejia Wang , \\ Otgonbayar Yadamjav8
}

\author{
${ }^{1}$ College of Environmental Science and Engineering, Donghua University, Shanghai, China \\ ${ }^{2}$ State Key Laboratory of Simulation and Regulation of Water Cycle in River Basin, China Institute of Water Resources and \\ Hydropower Research (IWHR), Beijing, China \\ ${ }^{3}$ Department of Water Resources, China Institute of Water Resources and Hydropower Research (IWHR), Beijing, China \\ ${ }^{4}$ Bio-Taq Economy Innovations (BioTEI) Inc., Winnipeg, Canada \\ ${ }^{5}$ Department of Natural Resource Management, University of Gondar, Gondar, Ethiopia \\ ${ }^{6}$ Department of Environment and Forest Engineering, School of Engineering and Applied Sciences, National University of \\ Mongolia, Ulaanbaatar, Mongolia \\ ${ }^{7}$ Department of Hydraulic Engineering, Tsinghua University, Beijing, China \\ ${ }^{8}$ Department of Sociology and Social Work, School of Art \& Sciences, National University of Mongolia, Ulaanbaatar, Mongolia \\ Email: *Yandh@iwhr.com
}

How to cite this paper: Cherinet, A.A., Yan, D.H., Wang, H., Song, X.S., Qin, T.L., Kassa, M.T., Girma, A., Dorjsuren, B., Gedefaw, M., Wang, H.J. and Yadamjav, O. (2019) Climate Trends of Temperature, Precipitation and River Discharge in the Abbay River Basin in Ethiopia. Journal of Water Resource and Protection, 11, 1292-1311.

https://doi.org/10.4236/jwarp.2019.1110075

Received: May 20, 2019

Accepted: October 21, 2019

Published: October 24, 2019

Copyright $\odot 2019$ by author(s) and Scientific Research Publishing Inc. This work is licensed under the Creative Commons Attribution International License (CC BY 4.0).

http://creativecommons.org/licenses/by/4.0/

\section{Open Access}

\begin{abstract}
Projecting future changes of streamflow in the Abby River Basin (ARB) is important for planning and proper management of the basin system. The current study conducted in five stations of the Abbay river basin, and investigated the annual temperature, precipitation, and river discharge variability using the Innovative trend analysis method, Mann-Kendall, and Sen's slope test estimator. The result showed a slightly increasing trend of annual precipitation in Assoa ( $Z=0.71)$, Bahir Dar $(Z=0.13)$, and Gonder $(Z=0.26)$ stations, while a significant increasing trend was observed in Nedgo $(Z=2.45)$ and Motta $(Z=1.06)$ stations. Interestingly, the trend of annual temperature in Assosa $(Z=5.88)$, Bahir Dar $(Z=3.87)$, Gonder $(Z=4.38)$, Nedgo $(Z=$ $4.77)$, and Motta $(Z=2.85)$ was abruptly increased. The average mean temperature has increased by $0.2^{\circ} \mathrm{C}$ in the past 36 years (1980 to 2016). The extreme high temperature was observed in the semi-dry zone of northern Ethiopia. During the study period, a significant declining trend of the river discharge was recorded, and the river discharge was sharply decreased from 1992 onwards. The results of the current study showed annual variability of river discharge, precipitation, and temperature of the study area of the basin that could be used as a basis for future studies.
\end{abstract}




\section{Keywords}

Abbay River Basin, Climate Change, Ethiopia, Precipitation, River Discharge, Temperature

\section{Introduction}

According to the various reports of IPCC Global average temperature of the sea, the land surface has revealed an increasing trend over the past 100 years which has led to increasing the sea level, and decreased the snowfall as well as glaciers. Due to this reason, global warming may threaten human life, and the occurrence probability may increase through extreme weather (i.e. heavy rainfall, heat waves, flooding, and drought) [1] [2]. Surface temperature globally increased by $0.85^{\circ} \mathrm{C}$ in the 20th century, and this drift had been even more significant over the past 30 years [3] [4]. The atmospheric moisture content is higher than before, due to a warmer climate that affects the earth's hydrological cycle [5]. River discharge is an important factor in agricultural, environmental, and economic applications [6]. Thus, investigating changes in river discharge considering future climate conditions to understand the effects of climate change. River discharge and climate variability have a huge economic impact particularly on hydropower generation and rained agriculture [7]. It is therefore imperative to study the patterns of climate trends in the Abay river basin and its impacts on water availability in the region.

The Nile Basin is one of the water river resources from Africa continent and the longest river channels in the world. The evolution of modern drainage network and its fluvial geomorphology reflect both long-term tectonic and volcanic processes and the associated changes in erosion and sedimentation, in addition to sea level changes [8]. A recent study [9] showed that in the past century, human activities affected the land use change and large dam construction projects had huge impacts on the hydrology and sediment budget of the Basin. It is unique among the large exotic rivers of the world in that it flows for almost 2700 $\mathrm{km}$ through the Sahara Desert without any significant perennial tributary inputs. The Nile River basin served as the place for the evolution and decay of advanced civilizations in the ancient world. On the banks of the river dwelled residents who were among the first to cultivate the arts of agriculture and use of plowing implements [9].

The Blue Nile River is the largest tributary and major source of the Nile River. The Basin is located in the northwestern region of Ethiopia. The part of the Blue Nile basin in Ethiopia is called Abbay River Basin and it covers an area of $199,592.17 \mathrm{~km}^{2}$ [10]. The country's largest freshwater lake, Lake Tana, is the source of the Abbay River Basin and is located north of the basin [11] [12] [13]. The Abbay river basin is a land of dramatic gorges, and mountain is the most important river basin in Ethiopia. 
Trends in precipitation, temperatures and Discharge are useful indicators of climate variability and change [14]. Due to this fact, the current study present trends of climate variability and river discharge in the Abbay river basin were analyzed. Linear trends and equivalent levels of importance were calculated for time series of annual and monthly maxima and the corresponding means respectively. The total annual precipitation and standard deviations for all variables were analyzed taking trends into account. Additionally, stabilization on linear trends was analyzed through a reverse arrangement test. It was also shown that monthly precipitation trends could be weakly linked to climate indices. Thus, the study conducted a linear correlation analysis between monthly precipitation amounts and the climate variability in the Abbay river basin. The main aims of this study are to examine climatic trends in ARB, to observe the historical variants in temperature, precipitation, and river discharge in the basin, and finally, evaluate the correlation among climatic variables and river discharge in the basin.

\section{Materials and Methods}

\subsection{Study Area}

The Abbay River Basin the major tributary and that is found in the northwestern part of Ethiopia, and it is located in the dry and semi-dry region while it is considered the main source of water supply for Ethiopia, Egypt, and Sudan. The basin is a major tributary of the Nile River and supplies about $62 \%$ of the flow that reaches the Aswan Dam [10] [15]. The Study showed that Abbay river basin, with a drainage area approximately $199592.17 \mathrm{~km}^{2}$, Figure 1 and covers a large part of the Ethiopian Highlands [16]. It sustains more than 179,106 people [9] between longitudes $34^{\circ} 300$ and $39^{\circ} 450 \mathrm{E}$ and latitudes $7^{\circ} 450$ and $12^{\circ} 450 \mathrm{~N}$.

\subsection{Data Sources}

Temperature, precipitation and hydrological data of the ARB were sourced from Ethiopia National Meteorology Agency (NMA), and Institute of Ethiopia Water Resource (IEWR). The locations of the five stations used in the study are shown in Figure 1, and detailed information about the five stations is shown in Table 1.

Table 1. List of Metrological station, river near to station, region and geographical recognition in the study river basin.

\begin{tabular}{ccccccc}
\hline $\begin{array}{c}\text { Nearby } \\
\text { city }\end{array}$ & $\begin{array}{c}\text { River } \\
\text { name }\end{array}$ & $\begin{array}{c}\text { Station } \\
\text { name }\end{array}$ & $\begin{array}{c}\text { Latitude } \\
\text { N }\end{array}$ & $\begin{array}{c}\text { Longitude } \\
\text { E }\end{array}$ & $\begin{array}{c}\text { Annual Mean } \\
\text { precipitation } \\
(\mathbf{m m})\end{array}$ & $\begin{array}{c}\text { Annual Mean } \\
\text { temperature } \\
\left({ }^{\circ} \mathrm{C}\right)\end{array}$ \\
\hline Assosa & Dabus & Assosa & $10^{\circ} 4.002^{\prime}$ & $34^{\circ} 31.99^{\prime}$ & 690.1 & 21.64 \\
Bahir Dar & Abbay & Bahirdar & $11^{\circ} 36^{\prime} 0^{\prime \prime}$ & $37^{\circ} 22^{\prime} 60^{\prime \prime}$ & 656.75 & 19.82 \\
Gonder & $\begin{array}{c}\text { Megeche } \\
\text { Azezo }\end{array}$ & Gonder & $12^{\circ} 36^{\prime} 0^{\prime \prime}$ & $37^{\circ} 28^{\prime} 0^{\prime \prime}$ & 1102.15 & 20.25 \\
Nedjo & Aleltu & Nedjo & $9^{\circ} 30^{\prime} 0^{\prime \prime}$ & $35^{\circ} 30^{\prime} 0^{\prime \prime}$ & 994.20 & 19.00 \\
Motta & Teme & Motta & $11^{\circ} 5^{\prime} 0^{\prime \prime}$ & $37^{\circ} 52^{\prime} 0^{\prime \prime}$ & 1142.95 & 17.00 \\
\hline
\end{tabular}




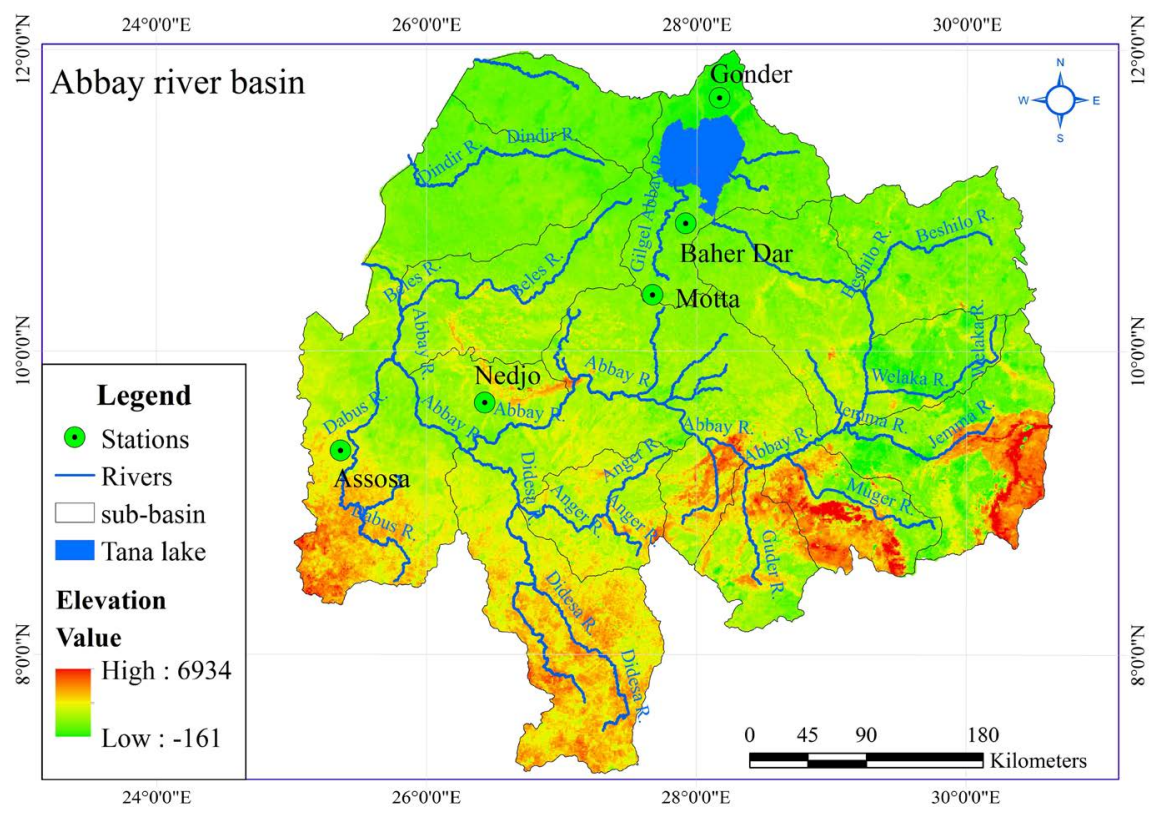

Figure 1. Map of Ethiopia and location of the study area with rivers and Lake Tana.

Meteorological features and Physic-geographical regionalization and location of climate stations are further described in Table 1. Climate and water gauge stations in the ARB were selected based on the following factors: 1) location and dispersion of stations; 2) capacity of the station; 3) physic-geographical regionalization of the station; and 4) whether it is close to the water system (Figure 1) [17] [18].

\subsection{Methods}

To evaluate the trends of all variable in both the observed and adjusted data were conducted using the Mann-Kendall test. This is the best approach, and well suited to determine changes in hydrologic regimes [19]. The Appendix [20] provides a concise description of the statistics applied to river discharge data [21], and it avoids the influence of serial correlations on the trend analyses. Trends in precipitation, temperatures, and discharge are useful indicators of climate variability and change [14]. The trend analysis is used to investigate whether the trend is increasing, decreasing, or shows no data value points. Non-parametric MK test data has been implemented in more studies to identify trends in the hydro-metrological observations that do not require regular distribution of data points. The study uses the ITAM to observe the trends in precipitation time series data. The result of ITAM was compared with MK and Sen's slope estimator test to evaluate the reliability of the test. Furthermore, annual and seasonal precipitation variability time series data were considered by ITAM. The study region has four distinct seasons: Summer in Ethiopian Amharic language called "Kiremet" or "Meher" (June-August), Autumn in Amharic "Belg” (September-November), winter in Amharic "Bega" (December-February) and spring in Amharic "Tseday" (March-May). Significance levels at $10 \%, 5 \%$, and $1 \%$ were tested to assess the 
climate and river discharge time's series data by MK, ITAM, and Sen's slope estimator method. A significance level of $10 \%$ was considered as a threshold level to show a significant trend. The summer season in the studied area is characterized by heavy rainfall [22].

\subsubsection{Mann-Kendall Trend Test}

The Mann Kendall (MK) test method is a non-parametric test ordinarily used to investigate trends of hydro-meteorological time series data [19] [23] [24] [25]. In the present study, it's used to detect the annual precipitation and temperature time series data [26] [27] [28]. The Mann-Kendall test statistics " $S$ " is given as:

$$
\begin{gathered}
S=\sum_{i=1}^{n-1} \sum_{j=i+1}^{n} \operatorname{sgn}\left(x_{j}-x_{i}\right) \\
\operatorname{sgn}\left(x_{j}-x_{i}\right)= \begin{cases}+1 & \text { if }\left(x_{j}-x_{i}\right)>0 \\
0 & \text { if }\left(x_{j}-x_{i}\right)=0 \\
-1 & \text { if }\left(x_{j}-x_{i}\right)<0\end{cases}
\end{gathered}
$$

where $x_{j}$ and $x_{i}$ represent the data points in period $j$ and $i$. While the amount of data series is larger than or equivalent to ten $(n \geq 10)$, M-K test is then categorized by a standard distribution with the mean $E(S)=0$ and variance $\operatorname{Var}(S)$ is given as [19] [24] [29]:

$$
\begin{gathered}
E(S)=0 \\
\operatorname{Var}(S)=\frac{n(n-1)(2 n+5)-\sum_{k=1}^{m} t_{k}\left(t_{k}-1\right)\left(2 t_{k}+5\right)}{18}
\end{gathered}
$$

where $m$ is the number of the tied groups in the time series, and $t_{k}$ is the number of ties in the $k$ th tied group. From this the test $Z$ statistics are obtained using an approximation as follows:

$$
Z= \begin{cases}\frac{s-1}{\delta}, & \text { if } S>0 \\ 0, & \text { if } S=0 \\ \frac{s+1}{\delta}, & \text { if } S<0\end{cases}
$$

Positive $Z$ value indicated an increasing trend whereas, negative $Z$ value indicates a decreasing trend.

\subsubsection{Sen's Slope Trend Detection}

The magnitude of the trend is computed by slope trend detection methods [30] [31]. For two data points the slope $Q_{i}$ is equated as:

$$
Q_{i}=\frac{x_{j}-x_{k}}{j-k} \text {, for } i=1,2, \cdots, N
$$

where $x_{j}$ and $x_{k}$ stand for data points at the phase $j$ and $(j>k)$, correspondingly. Once here is solitary datum for each period, at that time $N=(n(n-1)) / 2$; where, $n$ is the numeral time epochs. Conversely, if the amount of data for each year is numerous, at that time $N<(n(n-1)) / 2$; the $n$ 
the total number of observations [32]. The $N$ values in the slope trend test detector are organized from lowest to largest. The median of slope $(\beta)$ is equated

as:

$$
\beta=\left\{\begin{array}{l}
Q[(N+1) / 2] \\
Q[(N / 2)+Q(N+2) /(2) /(2)]
\end{array}\right.
$$

The symbol of $\beta$ displayed the trend is upward or downward.

\subsubsection{Innovative Trend Detection Method (ITAM)}

Innovative trend detection method $(\mathrm{M})$ has been widely used to detect the trends of meteorological variables. The ITA splits a time series data into two equivalent fragments and it categorizes both sub-series in ascending direction. The two splits positioned on a coordinate system $\left(x_{i}: i=1,2,3, \cdots, n / 2\right)$ on $\mathrm{X}$-axis and $\left(x_{j}: j=n / 2+1, n / 2+2, \cdots, n\right)$ on $\mathrm{Y}$-axis. If the time series data on dispersed plots are composed on the $45^{\circ}$ (1:1) conventional line, it indicates no tendency. On the other hand, the tendency is increasing once data points gathered beyond the 1:1 conventional line and the tendency is declining when data points gathered below the 1:1 conventional line [22] [33]. The average value variance among $x_{i}$ and $x_{j}$ can give the tendency magnitude of the data series. The total number of experimental data points for this study spans 36 years (1980-2016). The ITA is equated as:

$$
\phi=\frac{1}{n} \sum_{i=1}^{n} \frac{10\left(x_{j}-x_{i}\right)}{\mu}
$$

where $\phi$ represents trend indicator, $n$ stands for the number of observation on the subseries, $x_{i}$ is the data series in the first half subseries class, $x_{j}$ is the data series in the second half subseries class and $\mu$ represents the average data series in the first half sub series class. A positive and negative value of $\phi$ indicates an upward and downward trend respectively. However, when the scatter points are contiguous around the 1:1 conventional line, it indicates the absence of a significant trend [22] [33] [34].

\section{Results}

\subsection{Analysis of Precipitation}

Annual mean precipitation of the study area from 1980 to 2016 was $295.2 \mathrm{~mm}$. The minimum and maximum recorded annual average precipitations were 175.0 and $380.0 \mathrm{~mm}$ respectively. A significant decrease in precipitation was observed in the years 1994 and 1996 respectively. However, in general, little increase in precipitation was observed $\left(\mathrm{R}^{2}=0.0106\right)$ during this period. The seasonal precipitation varied; spring $39.27 \mathrm{~mm}$ (13.3\%) to Summer $204.11 \mathrm{~mm}$ (69.15\%), autumn $43.51 \mathrm{~mm}$ (14.74\%) to Winter $8.29 \mathrm{~mm}$ (2.81\%) (Table 2).

An analysis of the annual trend of precipitation in the listed station was using the ITAM, MK, and Sen's slope estimator test result are demonstrated in Table 3. The MK curve annual precipitation shows a statistically significant increasing 
trend in Motta from 1990 to $2015(Z=7.05)$ and in Bahir Dar from 1990 to 2015 ( $Z=6.92)$. In Gonder from 1995 to $2015(Z=1.95)$, in Assosa from 2000 to 2015 $(Z=1.20)$, in Nedjo from 1993 to $2016(Z=-3.53)$. In general, the average significant increasing trend was observed in five stations $(Z=3.88)$ (Figure 2).

Table 2. Monthly and seasonal precipitation of stations.

\begin{tabular}{|c|c|c|c|c|c|c|c|}
\hline $\begin{array}{l}\text { Months, } \\
\text { season }\end{array}$ & $\begin{array}{l}\text { Assosa } \\
(\mathrm{mm})\end{array}$ & $\begin{array}{l}\text { Bahir Dar } \\
(\mathrm{mm})\end{array}$ & $\begin{array}{c}\text { Gonder } \\
(\mathrm{mm})\end{array}$ & $\begin{array}{l}\text { Nedjo } \\
(\mathrm{mm})\end{array}$ & $\begin{array}{l}\text { Motta } \\
(\mathrm{mm})\end{array}$ & $\begin{array}{c}\text { Average } \\
\text { precipitati } \\
\text { on }(\mathrm{mm})\end{array}$ & $Z$-Score \\
\hline January & 7.632 & 1.046 & 5.212 & 1.039 & 2.146 & 3.415 & -0.936 \\
\hline February & 3.614 & 0.382 & 14.131 & 2.174 & 2.082 & 4.477 & -0.919 \\
\hline March & 13.543 & 10.807 & 38.522 & 9.526 & 10.815 & 16.642 & -0.721 \\
\hline April & 22.302 & 13.042 & 96.759 & 17.034 & 18.652 & 33.558 & -0.446 \\
\hline May & 21.496 & 44.270 & 193.900 & 77.645 & 30.795 & 73.621 & 0.204 \\
\hline June & 9.766 & 122.387 & 347.185 & 81.389 & 44.928 & 121.131 & 0.976 \\
\hline July & 53.182 & 281.820 & 426.070 & 83.064 & 122.029 & 193.233 & 2.147 \\
\hline August & 68.415 & 212.534 & 283.651 & 78.907 & 119.151 & 152.532 & 1.486 \\
\hline September & 21.216 & 112.327 & 129.954 & 69.760 & 67.476 & 80.147 & 0.310 \\
\hline October & 15.342 & 44.828 & 64.874 & 27.962 & 41.911 & 38.983 & -0.358 \\
\hline November & 8.605 & 5.440 & 21.103 & 4.266 & 12.934 & 10.470 & -0.821 \\
\hline December & 7.441 & 2.702 & 5.699 & 1.035 & 4.272 & 4.230 & -0.923 \\
\hline Kiremt & 131.364 & 616.740 & 1056.906 & 243.360 & $\begin{array}{c}286.108 \\
(63.75 \%)\end{array}$ & 466.896 & 6.591 \\
\hline Meher & 45.163 & 162.595 & 215.931 & 101.987 & $\begin{array}{c}122.321 \\
(17.69 \%)\end{array}$ & 129.600 & 1.113 \\
\hline Bega & 18.687 & 4.130 & 25.042 & 4.248 & $\begin{array}{c}8.501 \\
(1.65 \%)\end{array}$ & 12.122 & -0.794 \\
\hline Belg & 57.341 & 68.119 & 329.180 & 104.205 & $\begin{array}{c}60.262 \\
(16.91 \%)\end{array}$ & 123.821 & 1.020 \\
\hline $\begin{array}{c}\text { Annual } \\
\text { precipitation }\end{array}$ & 252.555 & 851.584 & 1627.059 & 453.800 & $\begin{array}{c}477.192 \\
(100 \%)\end{array}$ & 732.438 & 10.904 \\
\hline
\end{tabular}

Table 3. Result for precipitation of $Z$-statistic of MK, IMAM ( $\phi)$, and Sen's slope estimator test $(\beta)$.

\begin{tabular}{ccccc}
\hline S/No. & Name of stations & $Z(\mathrm{MK})$ & $\boldsymbol{\phi}$ & $\boldsymbol{\beta}$ \\
\hline 1 & Assosa & $1.20^{*}$ & $5.87^{\star * *}$ & 0.38 \\
2 & Bahir Dar & $6.92^{* * *}$ & $28.91^{\star * *}$ & $5.71^{\star * *}$ \\
3 & Nedjo & $-1.07^{*}$ & 0.02 & $-0.46^{* * *}$ \\
4 & Gondar & $1.95^{*}$ & $1.88^{*}$ & 0.44 \\
5 & Motta & $7.05^{* * *}$ & $14.82^{* * *}$ & 0.35 \\
6 & Average & $3.88^{* * *}$ & $3.04^{* * *}$ & 0.84 \\
\hline
\end{tabular}

${ }^{\star}$ Trends at 0.1 significance level; ${ }^{* *}$ Trends at 0.05 significance level; ${ }^{* *}$ Trends at 0.01 significance level. 


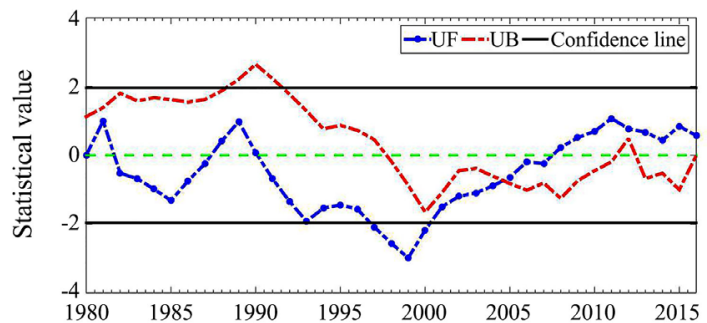

(a)

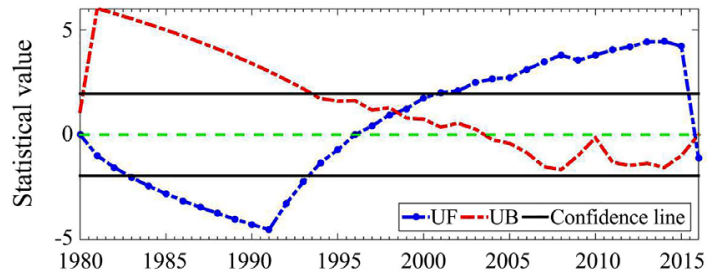

(b)

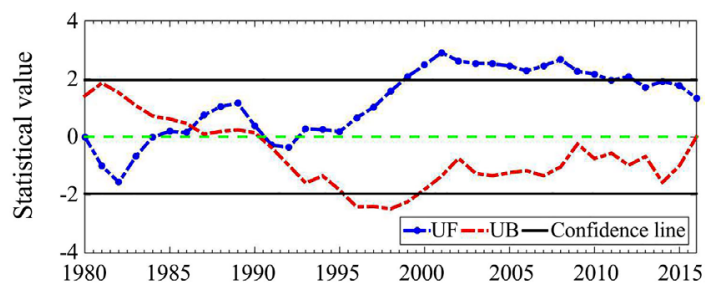

(c)

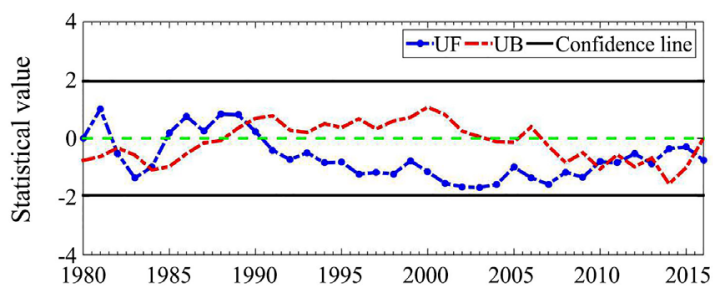

(d)

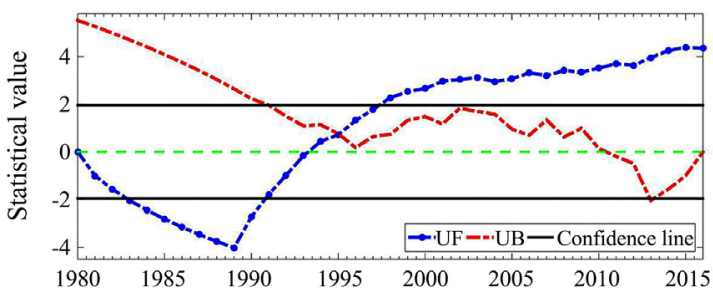

(e)

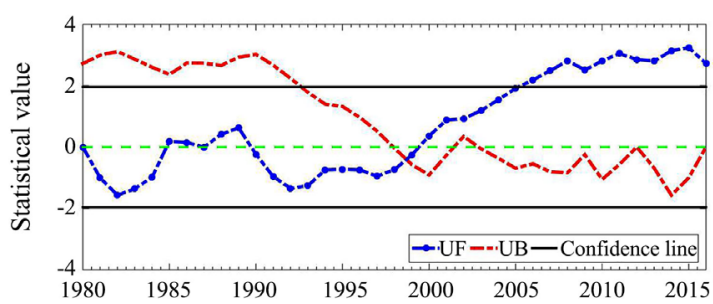

(f)

Figure 2. Trends of annual precipitation across stations (note: UF and UB are changing parameters where $\mathrm{UB}=-\mathrm{UF}$ ). (a) Assosa station; (b) Bahir Dar station; (c) Gonder station; (d) Nedjo station; (e) Motta station; (f) Average precipitation of the station. 


\subsection{Analysis of Temperature}

The MK curve annual temperature (changing parameters) shows a statistically significant increasing trend in Assosa from 1990 to $2015(Z=-2.61)$, Bahir Dar from 1990 to 2015 ( $Z=-2.63)$ Nedjo from 1993 to $2016(Z=-3.53)$, in Gonder from 1992 to 2015 ( $Z=6.96$ ), in Motta from 1986 to 2013 ( $Z=4.58$ ). In general, the average increasing trend was observed in five stations $(Z=0.75)$ (Figure 3$)$.

The annual trend analysis of temperature in all station using the $Z$-statistic of MK, IMAM ( $\phi)$, and Sen's slope estimator test $(\beta)$ test result is presented in Table 4. The trend in IMAM test shows an increasing trend in all stations. Thus, the increase and decrease in innovative trend analysis $\phi$ test value predict that the magnitude was strong.

\subsection{Analysis of River Discharge}

The MK curve annual river discharge (changing parameters) shows a sharply decreasing trend in Assosa from 1994 to $2016(Z=-3.32)$, a statistically significant decreasing trend in Gonder from 1982 to $2016(Z=-3.84)$, in Nedjo from 1990 to $2015(Z=-1.28)$, in Motta from 1995 to $2015(Z=-2.05)$. In general, a significant average decreasing trend was observed in five stations $(Z=-2.05)$ (Figure 4).

The results of the annual trend analysis of river discharge in all stations using the Mann Kendall test, ITAM, Sen's slope estimator are presented in Table 5. The trend in ITAM test shows a decreasing trend in all stations. Thus, the increase and decrease in innovative trend analysis $\phi$ test value predict that the magnitude was strong.

Table 4. Result for temperature of Z-statistic of MK, IMAM (ф), and Sen's slope estimator test $(\beta)$.

\begin{tabular}{ccccc}
\hline S/No. & Name of stations & $Z(\mathrm{MK})$ & $\phi$ & $\beta$ \\
\hline 1 & Assosa & $-2.61^{* *}$ & $2.63^{* *}$ & -0.03 \\
2 & Bahir Dar & $-2.63^{* *}$ & $-3.86^{* * *}$ & -0.02 \\
3 & Nedjo & $-3.53^{* * *}$ & $-1.78^{*}$ & -0.03 \\
4 & Gonder & $6.96^{* * *}$ & 0.40 & 0.04 \\
5 & Motta & $4.58^{* * *}$ & 0.30 & 0.03 \\
6 & Average & 0.75 & 0.12 & 0.00 \\
\hline
\end{tabular}

${ }^{\star}$ Trends at 0.1 significance level; ${ }^{* *}$ Trends at 0.05 significance level; ${ }^{* *}$ Trends at 0.01 significance level.

Table 5. Result for river discharge of $Z$-statistic of MK, IMAM (ф), and Sen's slope estimator test $(\beta)$.

\begin{tabular}{ccccc}
\hline S/No. & Name of stations & $Z(\mathrm{MK})$ & $\boldsymbol{\phi}$ & $\boldsymbol{\beta}$ \\
\hline 1 & Dabus Near Assosa & $-5.31^{\star * *}$ & $-2.67^{\star *}$ & $-8.06^{\star * *}$ \\
2 & Abbay Near Bahirdar & 0.99 & $1.64^{\star}$ & $1.69^{\star}$ \\
3 & Megeche Azezo Near Gonder & $3.02^{\star * *}$ & $3.53^{\star * *}$ & 0.27 \\
4 & Aleltu Near Nedjo & $-1.76^{*}$ & $-1.81^{\star}$ & -0.03 \\
5 & Teme Near Mota & $-1.11^{\star}$ & $-1.38^{\star}$ & -0.03 \\
\hline
\end{tabular}

${ }^{\star}$ Trends at 0.1 significance level; ${ }^{* *}$ Trends at 0.05 significance level; ${ }^{* *}$ Trends at 0.01 significance level. 


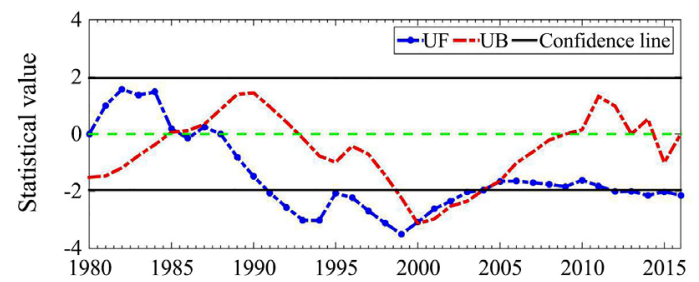

(a)

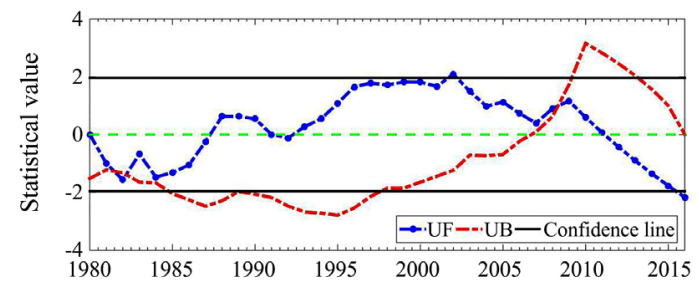

(b)

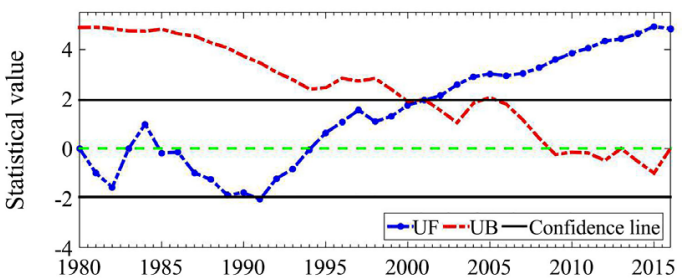

(c)

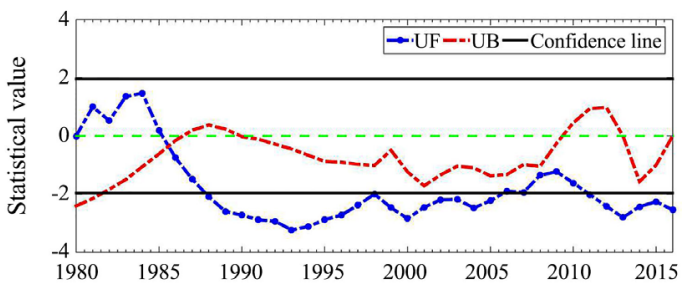

(d)

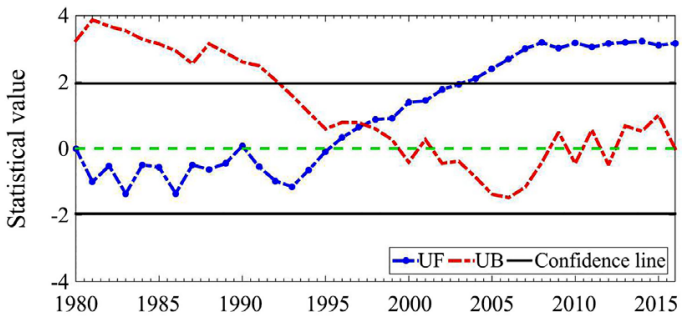

(e)

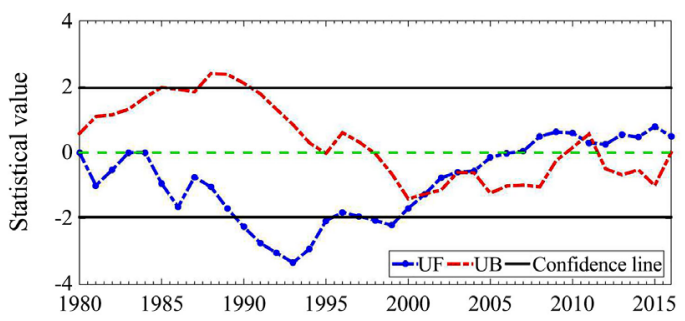

(f)

Figure 3. Trends of annual temperature across stations (note: UF and UB are changing parameters where UB = -UF). (a) Assosa station; (b) Bahir Dar station; (c) Gonder station; (d) Nedjo station; (e) Motta station; (f) Average temperature of the station. 


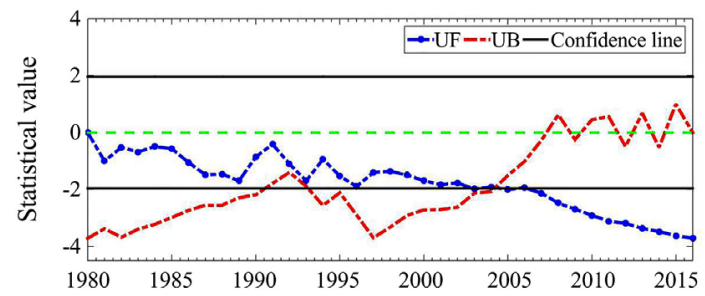

(a)

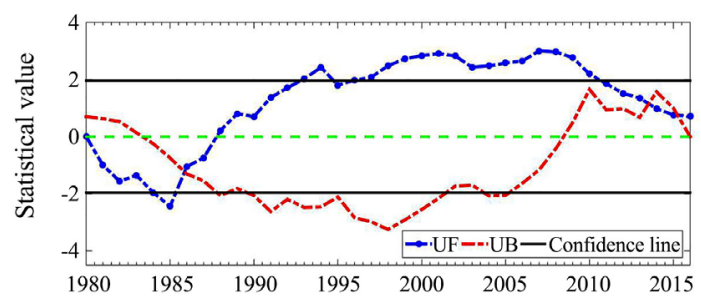

(b)

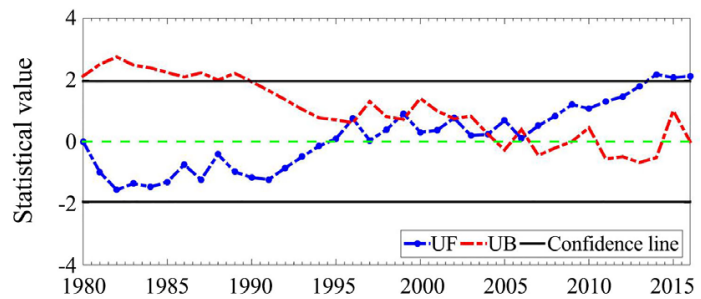

(c)

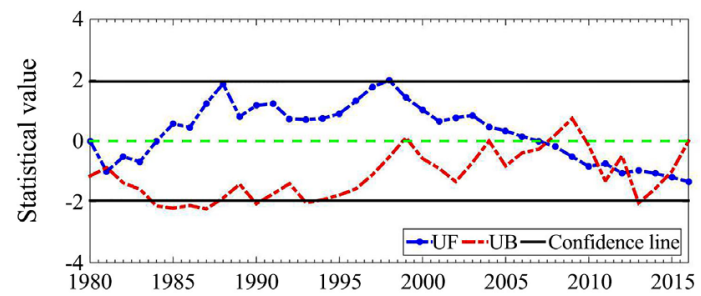

(d)

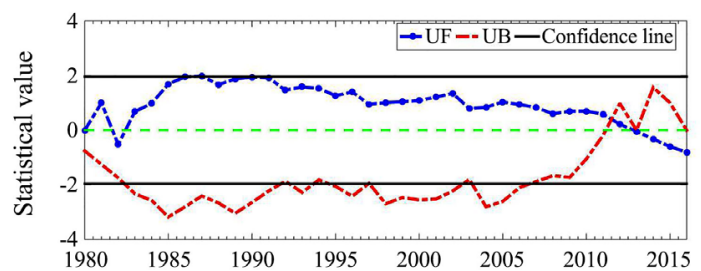

(e)

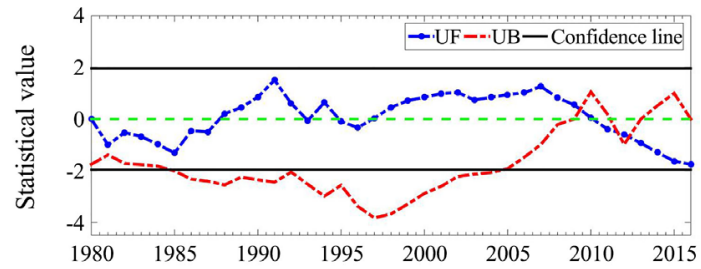

(f)

Figure 4. Trends of annual discharge across stations (note: UF and UB are changing parameters where UB = -UF). (a) Dabus Near Assosa station; (b) Abbay Near Bahir Dar station; (c) Megeche Azezo Near Assosa station; (d) Aleltu Near Nedjo station; (e) Teme Near Motta station; (f) Average discharge of the station. 


\subsection{Relationship of Stream Flow and Climate}

The rise of temperature is amongst the indices of global climate transformation. In the globe mean air temperature has increased by $0.85^{\circ} \mathrm{C}$ from 1880 onwards, which is expected to move higher in the near future [35] [36] [37] [38]. The global large inland water bodies temperature has been promptly heating ever since 1980, by the rate of $0.05 \pm 0.012^{\circ} \mathrm{C}$ /year and by the maximum rate of $0.1 \pm$ $0.011^{\circ} \mathrm{C} /$ year [39]. It has been detected abruptly upward trend of average annual air temperature in the upper reaches of $\mathrm{ARB}$ via $1.2^{\circ} \mathrm{C}$ or $0.021^{\circ} \mathrm{C} /$ year during the deliberated chronological period from 1980 to 2016. The increase is almost twofold of the mean heating rate worldwide $\left(0.012^{\circ} \mathrm{C} /\right.$ year $)$ [39]. The mean annual temperature of the basin was found to be $19.42^{\circ} \mathrm{C}$. A significant increase in temperature was observed from 1990 onwards (Figures 5-7). The average precipitation is $732.438 \mathrm{~mm} /$ year.

\section{Discussion}

In the study area, positive and negative results are present by the M-K test estimator, IT analysis, and Sen's slope test estimator. According to the results of the trend analysis, the annual mean precipitation displays temporal variations. It is consistent with the results of previous studies in parts of Northern Ethiopia. In general, the study area of the basin showed slight increase in precipitation but a decline in water accessibility [22] [39]. Anthropogenic factors, edaphic and topographic conditions in the region and affect the accessibility of water (unpublished data). But, most importantly, the high temperature increase in the region during the study period cause high level of evaporation that caused the decrease in water flow.

An increase in precipitation during the wet season disturbs the hydrological series and water resource supply for ecological units and the society [37]. Summer season is the major rainy period in the region that provides nearly $49.3 \%$ of the total precipitation that shows the prevalence of high intensity of rainfall. There is also optimum stream flow during the summer season. Diverse trend exploration studies have been piloted in Northern Ethiopia at diverse spatiotemporal measures and showed a wide range of results using different trend test parameters. The result of the present study is consistent with the results of the previous study [22] [40].

However, due to a small number of significant cases, only weak trends of increase in precipitation can be inferred. Most of the significant trends of the standard deviation in precipitation were negative. Thus, a trend towards a decrease in the variability of precipitation is concluded. The majority of the significant trends for the dry season were negative. However, for discharge, no clear trend could be evaluated as it is hard to quantify the influence of the anthropogenic factors. Both standard deviations of temperature and of river discharge show positive and negative significant trends. Thus, it is hard to draw a conclusion of a change in climate variability and river discharge. Clear positive trends 


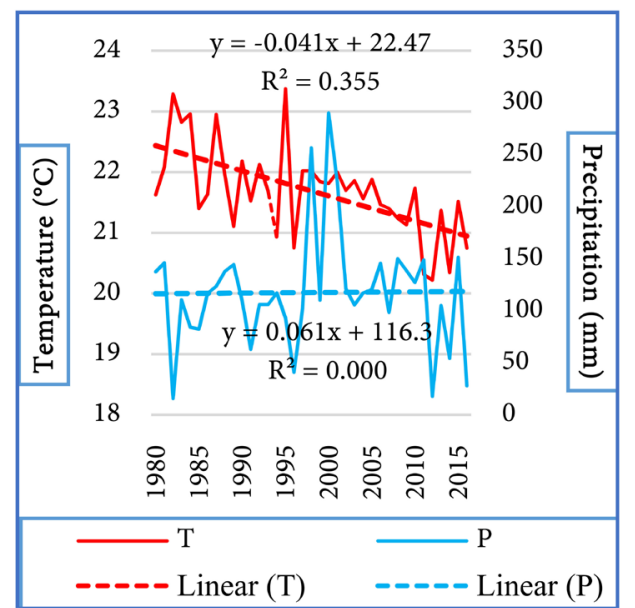

(a)

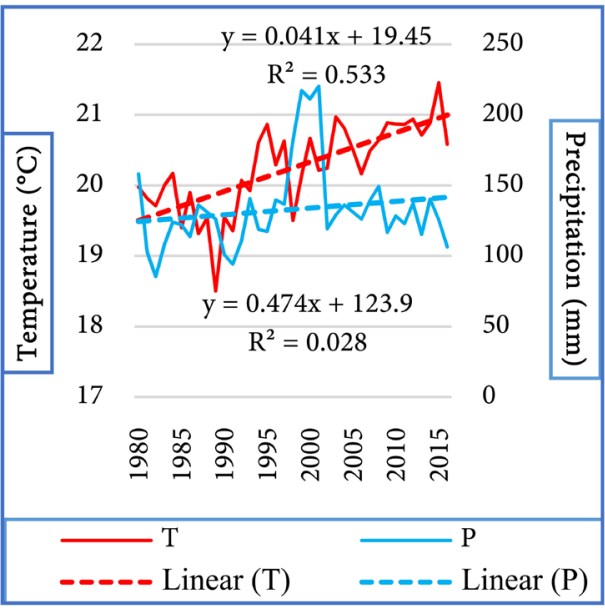

(c)

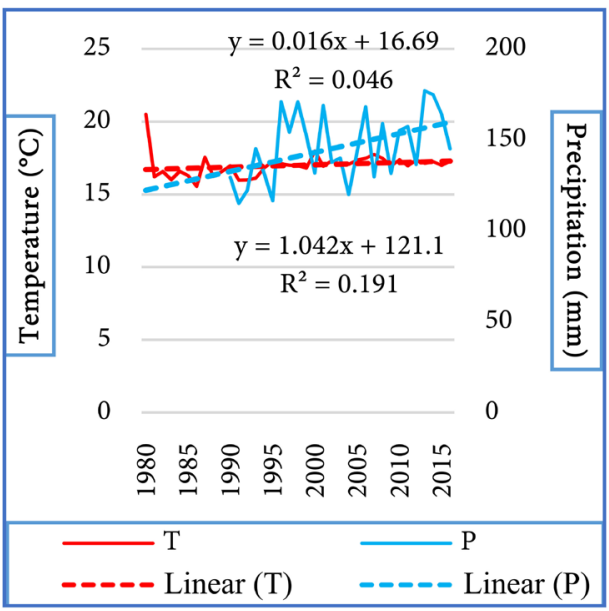

(e)

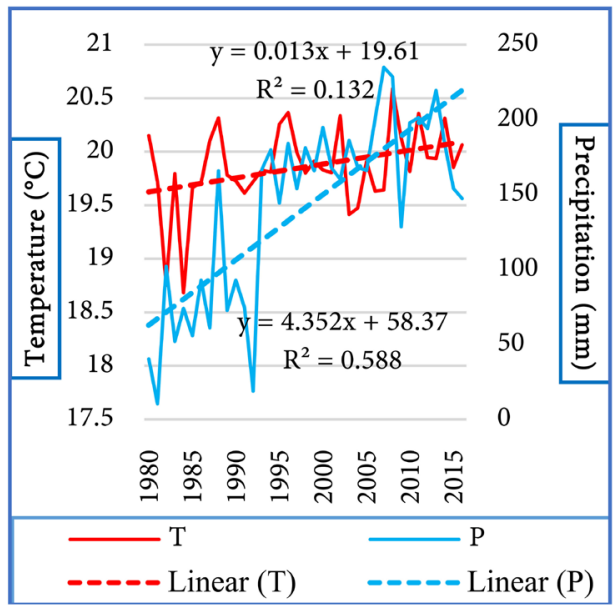

(b)

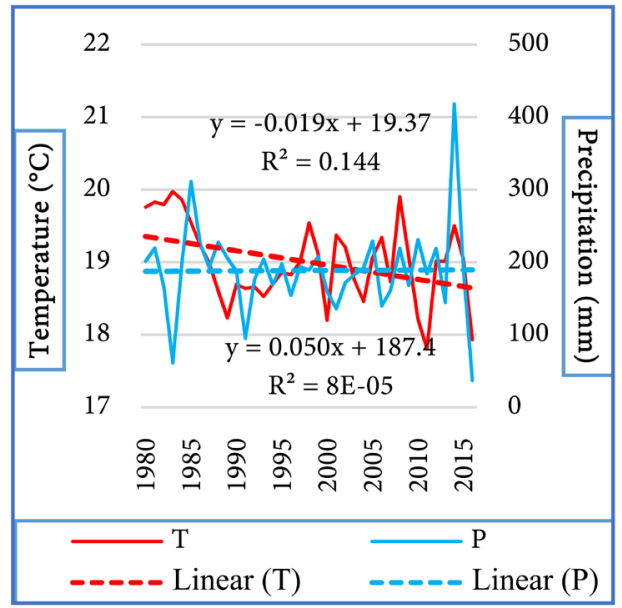

(d)

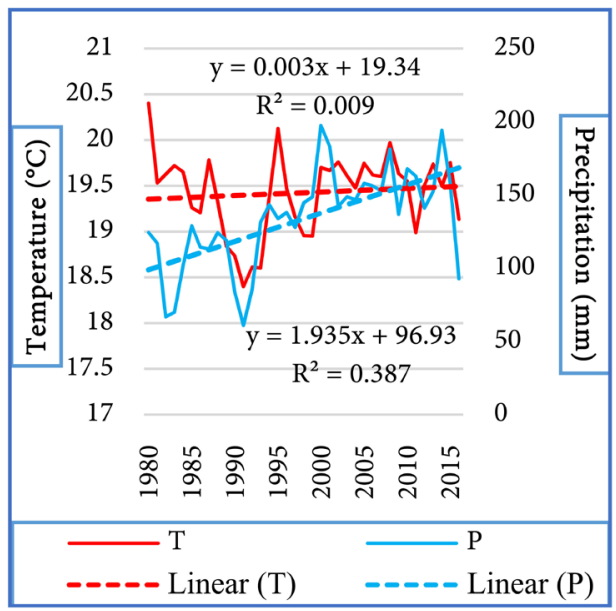

(f)

Figure 5. The temperature and precipitation trend for the period 1980-2016. The vertical column is temperature and horizontal column is precipitation change, and fluctuations line indicates annual values and breakdown lines indicate period running averages. (a) Asossa station; (b) Bahir Dar station; (c) Gonder station; (d) Nedjo station; (e) Motta Station; (f) Average. 


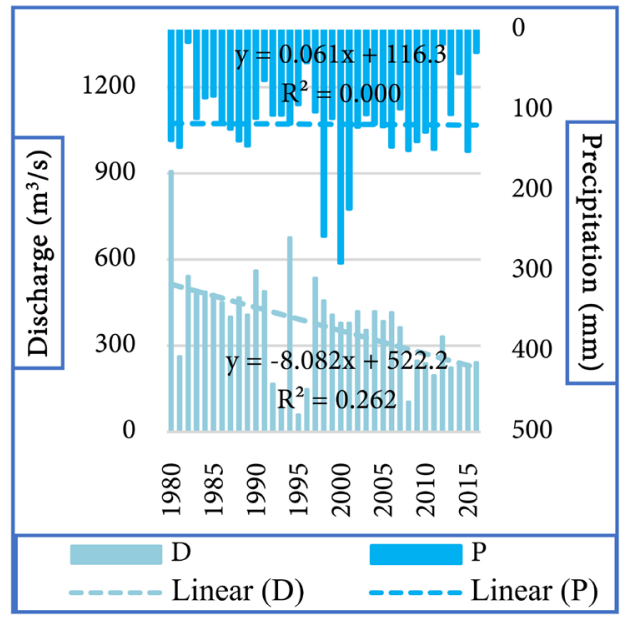

(a)

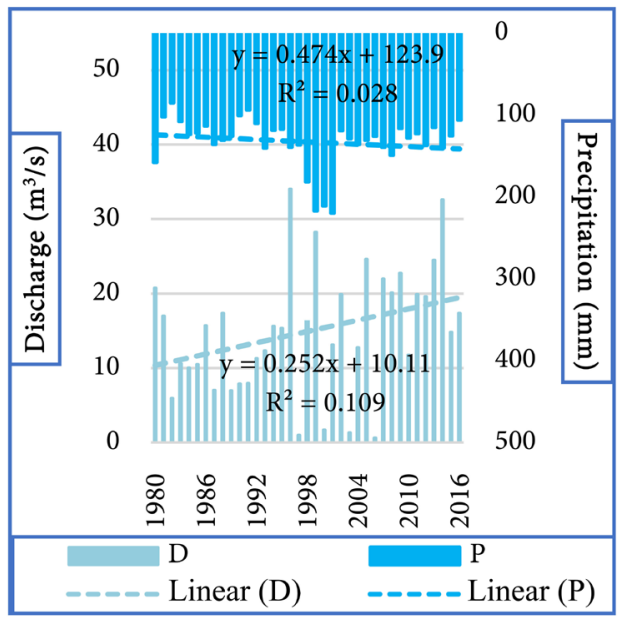

(c)

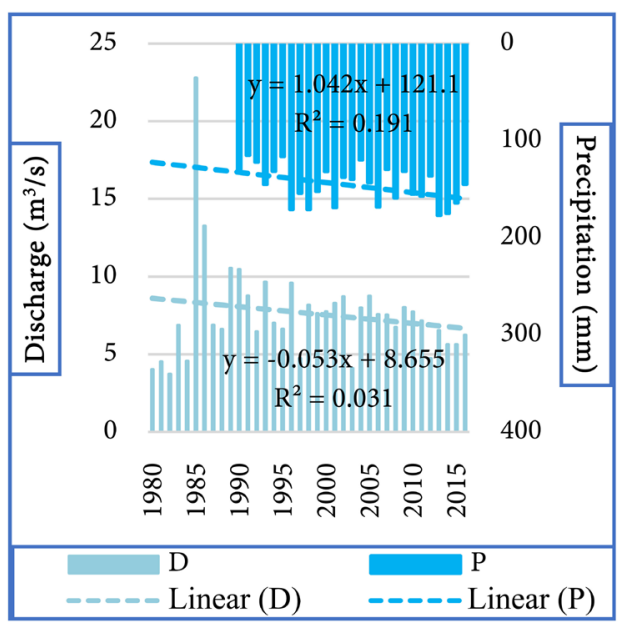

(e)

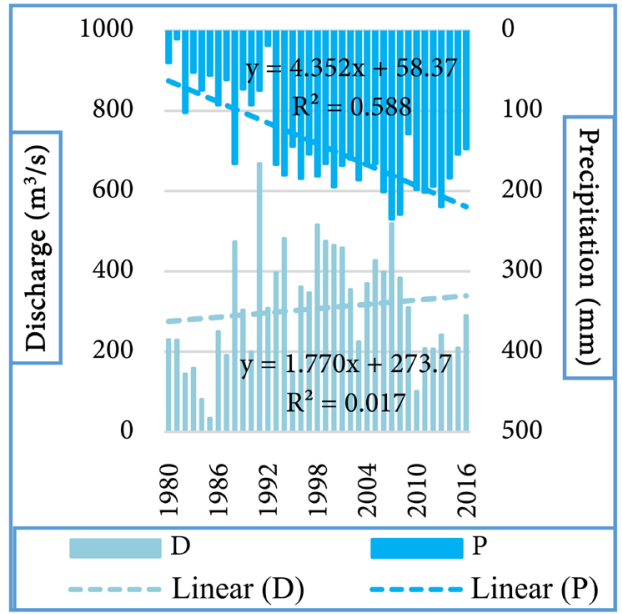

(b)

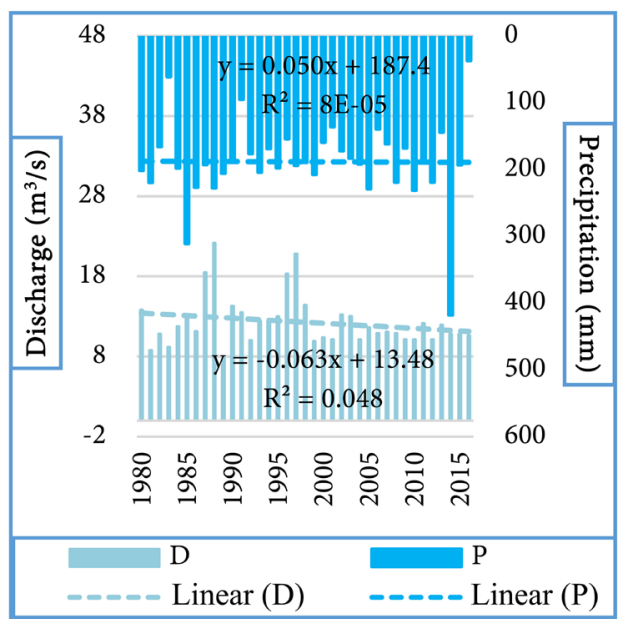

(d)

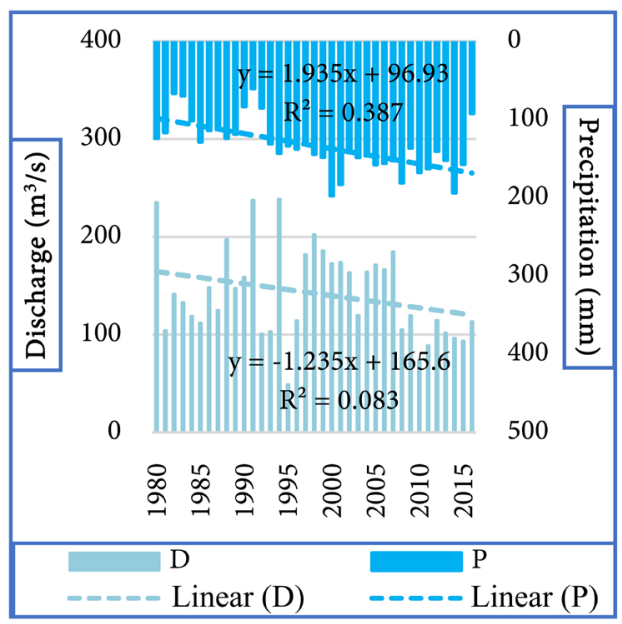

(f)

Figure 6. Long-term discharge and precipitation change, in during 1980-2016. (a) Dabus Near Assosa; (b) Abbay Near Bahir Dar; (c) Megeche Azezo Near Gonder; (d) Aleltu Near Nedjo; (e) Teme Near Motta; (f) Average. 


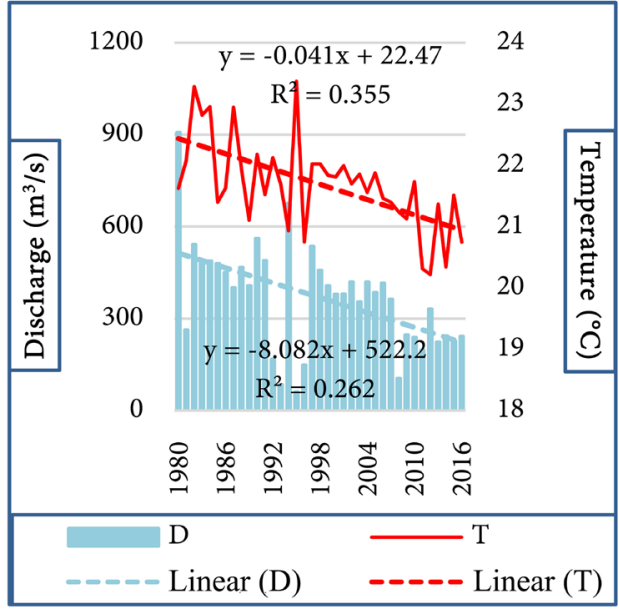

(a)

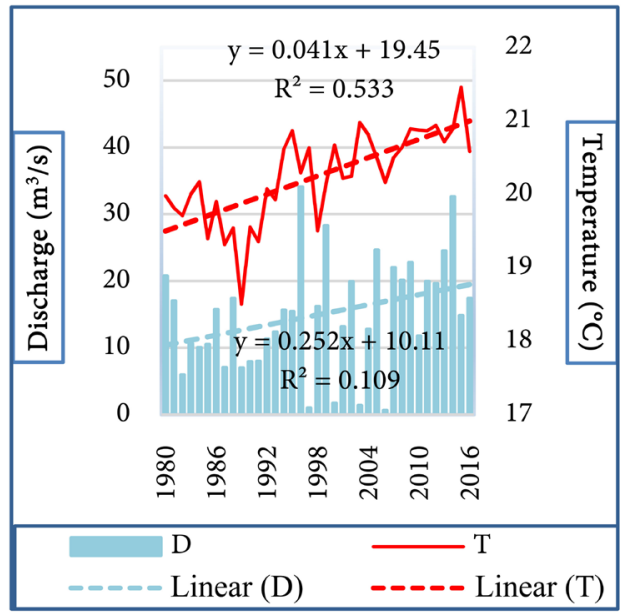

(c)

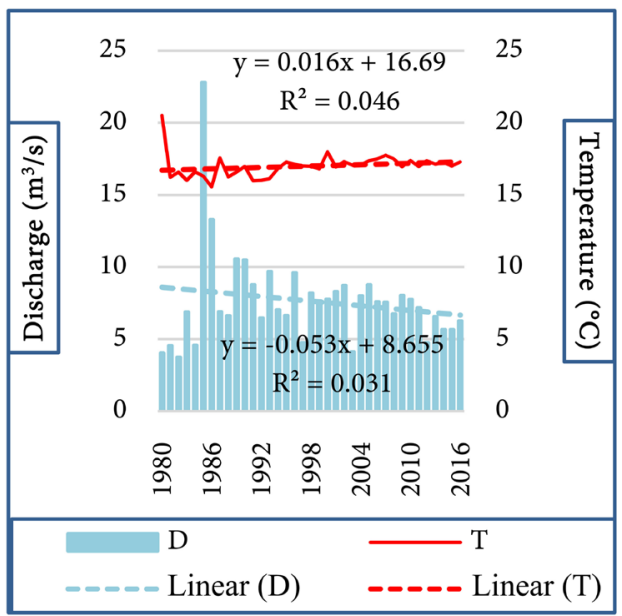

(e)

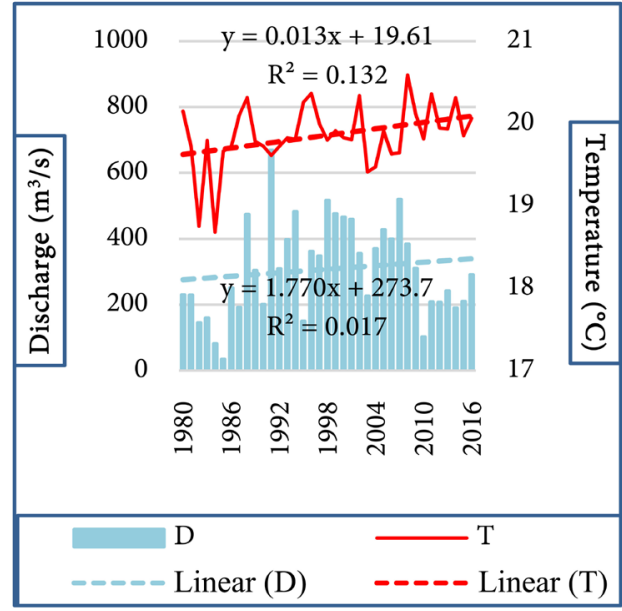

(b)

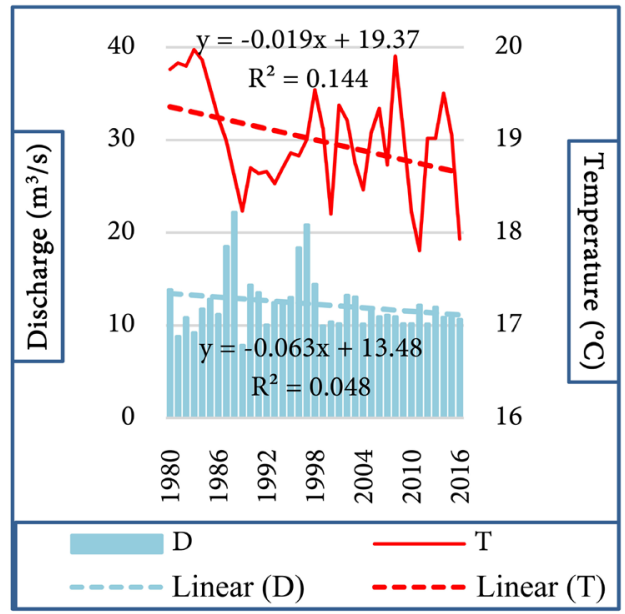

(d)

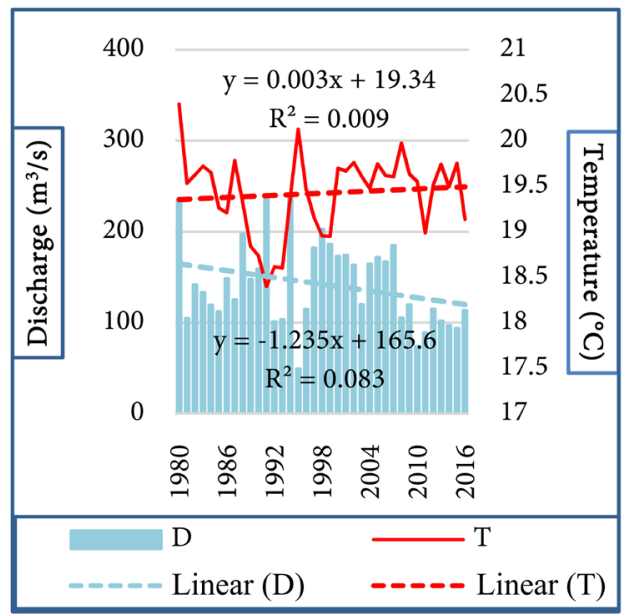

(f)

Figure 7. Long-term discharge and Temperature change, in during 1980-2016. (a) Dabus Near Assosa; (b) Abbay Near Bahir Dar; (c) Megeche Azezo Near Gonder; (d) Aleltu Near Nedjo; (e) Teme Near Motta; (f) Average. 
with high levels of significance were recognized for temperature time series and precipitation time series also showed significant positive trends, and both showed positive and negative trends across station. The correlation between climate variables and the observed changes in river discharge continues to debate. To determine this, it was considered the relationship between climate parameters, and stream flows (Figure 8).

The correlation coefficient between precipitation and river discharge has a negative correlation $(\mathrm{r}=-0.12)$ from 1990 to 2015. However, river discharge had declined sharply since 1985 (Figure 6) due to anthropogenic, edaphic, topographic factors and the high temperature increase in the region. The correlation coefficient between temperature and river discharge has a weak negative relationship ( $r=-0.0 .14$ ) from 1980 to 2016. In this case, the volume of the river discharge will decrease when the temperature increases. However, Figure 7 and Figure 8 showed that the river discharge had a significant decreasing trend since 1980. During this period, quantities of the river discharge passing through bigger cities are dramatically decreased. In particular, it is worth noting that human, topographic conditions, soil types, high socio-economic activities but most importantly the increase in temperature (which was the highest in semi-dry zone of northern Ethiopia for the past 40 years) negatively affected the amount of water flow in the river.

\section{Conclusions}

In the current study, the MK trend test, ITAM, and Sen's slope estimator test methods were used to analyze the variability of river discharge, temperature, and precipitation in an annual basis in the study area of the ARB. The temporal trend of temperature, precipitation, and river discharge was determined from 1980 to 2016. Seasonal variability of precipitation was studied in all sites. The slight upward trend was revealed for precipitation in Assosa, Bahir Dar, and Gonder stations, whereas, in Nedjo and Motta stations considerable increasing trend was observed. In the summer season, precipitation was sharply increased in the study area while a low amount of precipitation was observed in winter.

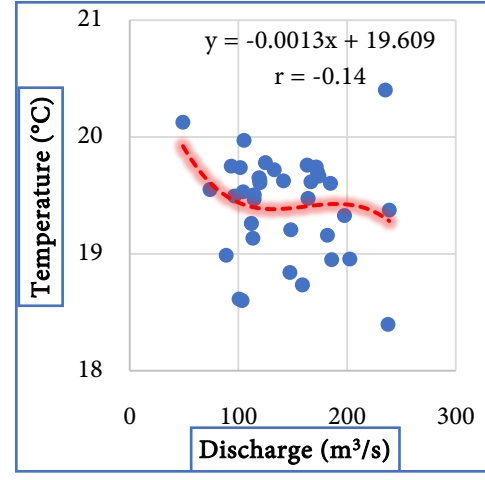

(a)

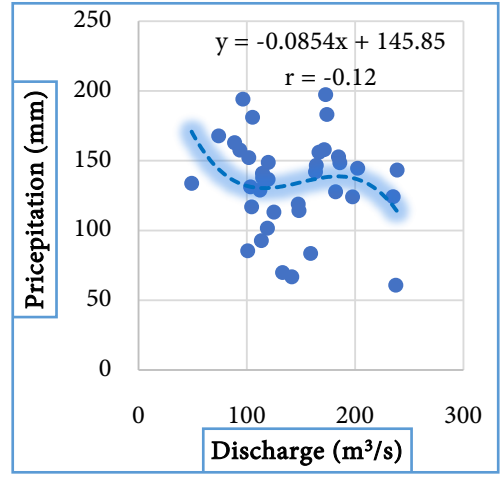

(b)

Figure 8. Correlation coefficient: (a) between temperature and discharge, (b) between precipitation and discharge. 
According to the result, the mean annual temperature of the ARB is $19.42^{\circ} \mathrm{C}$. The average temperature had increased by $0.2^{\circ} \mathrm{C}$ in the last 36 years. This was the highest in the semi-dry zone of northern Ethiopia for the past 40 years. This is significant for the global average warming rate. Precipitation is the main source of nourishment for the ARB. The basin runoff varies mostly because of variations of the summer precipitation. The river discharge trend is significantly decreased in the study periods. Particularly, it was higher since 1992 and could be due to the effects of human activities. The changes are coinciding with the climate change and human activity process in ARB of the Lake Tana. Thus future studies are warranted to understand the causes of river discharge change and its potential impacts on the Eco-hydrological systems in the basin area using distributed hydrological models.

\section{Acknowledgements}

The authors would like to thank the China Institute of Water Resources and Hydropower Research for financing this research. This research was funded by The China, National Key Research and Development Project (grant No. 2016YFA0601503).

\section{Conflicts of Interest}

The authors declare no conflicts of interest regarding the publication of this paper.

\section{References}

[1] IPCC, F.A.R. (2013) The Physical Science Basis. Contribution of Working Group I to the Fifth Assessment Report of the Intergovernmental Panel on Climate Change. Cambridge University Press, Cambridge and New York, 1535.

[2] IPCC (1990) Scientific Assessment of Climate Change.

[3] Papalexiou, S.M.A., Amir, T., Kevin, E. and Foufoula-Georgiou, E. (2018) Global, Regional, and Megacity Trends in the Highest Temperature of the Year. Earth's Future, 6, 71-79. https://doi.org/10.1002/2017EF000709

[4] Nashwan, M.S., Shahid, S. and Abd Rahim, N. (2018) Unidirectional Trends in Annual and Seasonal Climate and Extremes in Egypt. Theoretical and Applied Climatology, 136, 457-473. https://doi.org/10.1007/s00704-018-2498-1

[5] Hampton, S.E., Izmest'eva, L.R., Moore, M.V., Katz, S.L., Dennis, B. and Silow, E.A. (2008) Sixty Years of Environmental Change in the World's Largest Freshwater Lake-Lake Baikal, Siberia. Global Change Biology, 14, 1947-1958. https://doi.org/10.1111/j.1365-2486.2008.01616.x

[6] Livingstone, D.M. (1999) Ice Break-Up on Southern Lake Baikal and Its Relationship to Local and Regional Air Temperatures in Siberia and to the North Atlantic Oscillation. Limnology and Oceanography, 44, 1486-1497. https://doi.org/10.4319/lo.1999.44.6.1486

[7] Batsuren., D., Yan, D., Wang, H., Chonokhuu, S., Enkhbold, A., Davaasuren, D., Girma, A., Abiyu, A., Jing, L. and Gedefaw, M. (2018) Observed Trends of Climate and Land Cover Changes in Lake Baikal Basin. Environmental Earth Sciences, 77, 
725. https://doi.org/10.1007/s12665-018-7812-9

[8] UNESCO (2008) Sediment in the Nile River System. International Hydrological Programme International Sediment Initiative.

[9] Woodward, J.C., Macklin, M.G., Krom, M.D. and Williams, M.A.J. (2007) Evolution, Quaternary River Environments and Material Fluxes. In: Gupta, A., Ed., Large Rivers. Geomorphology and Management, Wiley, Chichester, 261-292. https://doi.org/10.1002/9780470723722.ch13

[10] Yilma, A.D. and Awulachew, S.B. (2009) Characterization and Atlas of the Blue Nile Basin and Its Sub Basins. Intermediate Results Dissemination Workshop, Addis Ababa, 5-6 February 2009, 236 p.

[11] Haregeweyn, N., Tsunekawa, A., Tsubo, M., Meshesha, D., Adgo, E., Poesen, J. and Schütt, B. (2016) Analyzing the Hydrologic Effects of Region-Wide Land and Water Development Interventions: A Case Study of the Upper Blue Nile Basin. Regional Environmental Change, 16, 951-966. https://doi.org/10.1007/s10113-015-0813-2

[12] Cherinet, A.A., Yan, D.H., Wang, H., et al. (2019) Impacts of Recent Climate Trends and Human Activity on the Land Cover Change of the Abbay River Basin in Ethiopia. Advances in Meteorology, 2019, Article ID: 5250870. https://doi.org/10.1155/2019/5250870

[13] Tekleab, S., Mohamed, Y. and Uhlenbrook, S. (2013) Hydro-Climatic Trends in the Abay/Upper Blue Nile Basin, Ethiopia. Physics and Chemistry of the Earth, Parts $A / B / C, 61-62,32-42$. https://doi.org/10.1016/j.pce.2013.04.017

[14] Braganza, K., Karoly, D.J. and Arblaster, J.M. (2004) Diurnal Temperature Range as an Index of Global Climate Change during the Twentieth Century. Geophysical Research Letters, 31, L13217. https://doi.org/10.1029/2004GL019998

[15] Roth, V., Lemann, T., Zeleke, G., Subhatu, A.T., Nigussie, T.K. and Hurni, H. (2018) Effects of Climate Change on Water Resources in the Upper Blue Nile Basin of Ethiopia. Heliyon, 4, e00771. https://doi.org/10.1016/j.heliyon.2018.e00771

[16] Lemann, T., Roth, V., Zeleke, G., Subhatu, A., Kassawmar, T. and Hurni, H. (2018) Spatial and Temporal Variability in Hydrological Responses of the Upper Blue Nile Basin, Ethiopia. Water, 11, 21. https://doi.org/10.3390/w11010021

[17] Ma, X., Yasunari, T., Ohata, T., Natsagdorj, L., Davaa, G. and Oyunbaatar, D. (2003) Hydrological Regime Analysis of the Selenge River Basin, Mongolia. Hydrological Processes, 17, 2929-2945. https://doi.org/10.1002/hyp.1442

[18] Sharma, K.P., Moore, B. and Vorosmarty, C.J. (2000) Anthropogenic, Climatic, and Hydrologic Trends in the Kosi Basin, Himalaya. Climatic Change, 47, 141-165. https://doi.org/10.1023/A:1005696808953

[19] Dorjsuren, B., Yan, D., Wang, H., Chonokhuu, S., Enkhbold, A., Yiran, X., Girma, A., Gedefaw, M. and Abiyu, A. (2018) Observed Trends of Climate and River Discharge in Mongolia's Selenga Sub-Basin of the Lake Baikal Basin. Water, 10, 1436. https://doi.org/10.3390/w10101436

[20] Atta-ur-Rahman, D.M. (2017) Spatio-Statistical Analysis of Temperature Fluctuation Using Mann-Kendall and Sen's Slope Approach. Climate Dynamics, 48, 783-797. https://doi.org/10.1007/s00382-016-3110-y

[21] McClelland, J.W., Déry, S.J., Peterson, B.J., Holmes, R.M. and Wood, E.F. (2006) A Pan-Arctic Evaluation of Changes in River Discharge during the Latter Half of the 20th Century. Geophysical Research Letters, 33, L06715. https://doi.org/10.1029/2006GL025753

[22] Gedefaw, M., Yan, D., Wang, H., Qin, T., Girma, A., Abiyu, A. and Batsuren, D. 
(2018) Innovative Trend Analysis of Annual and Seasonal Rainfall Variability in Amhara Regional State, Ethiopia. Atmosphere, 9, 326. https://doi.org/10.3390/atmos9090326

[23] Yue, S. and Wang, C. (2004) The Mann-Kendall Test Modified by Effective Sample Size to Detect Trend in Serially Correlated Hydrological Series. Water Resources Management, 18, 201-218. https://doi.org/10.1023/B:WARM.0000043140.61082.60

[24] Kisi, O. and Ay, M. (2014) Comparison of Mann-Kendall and Innovative Trend Method for Water Quality Parameters of the Kizilirmak River, Turkey. Journal of Hydrology, 513, 362-375. https://doi.org/10.1016/j.jhydrol.2014.03.005

[25] Asfaw, A., Simane, B., Hassen, A. and Bantider, A. (2018) Variability and Time Series Trend Analysis of Rainfall and Temperature in Northcentral Ethiopia: A Case Study in Woleka Sub-Basin. Weather and Climate Extremes, 19, 29-41. https://doi.org/10.1016/j.wace.2017.12.002

[26] Cui, L., Wang, L., Lai, Z., Tian, Q., Liu, W. and Li, J. (2017) Innovative Trend Analysis of Annual and Seasonal Air Temperature and Rainfall in the Yangtze River Basin, China during 1960-2015. Journal of Atmospheric and Solar-Terrestrial Physics, 164, 48-59. https://doi.org/10.1016/j.jastp.2017.08.001

[27] da Silva, R.M., Santos, C.A.G., Moreira, M., Corte-Real, J., Silva, V.C.L. and Medeiros, I.C. (2015) Rainfall and River Flow Trends Using Mann-Kendall and Sen's Slope Estimator Statistical Tests in the Cobres River Basin. Natural Hazards, 77, 1205-1221. https://doi.org/10.1007/s11069-015-1644-7

[28] Nourani, V., Danandeh Mehr, A. and Azad, N. (2018) Trend Analysis of Hydroclimatological Variables in Urmia Lake Basin Using Hybrid Wavelet Mann-Kendall and Şen Tests. Environmental Earth Sciences, 77, 207.

https://doi.org/10.1007/s12665-018-7390-x

[29] Easterling, D.R., Evans, J.L., Groisman, P.Y., Karl, T.R., Kunkel, K.E. and Ambenje, P. (2000) Observed Variability and Trends in Extreme Climate Events: A Brief Review. Bulletin of the American Meteorological Society, 81, 417-426. https://doi.org/10.1175/1520-0477(2000)081<0417:OVATIE >2.3.CO;2

[30] Gocic, M. and Trajkovic, S. (2013) Analysis of Changes in Meteorological Variables Using Mann-Kendall and Sen's Slope Estimator Statistical Tests in Serbia. Global and Planetary Change, 100, 172-182. https://doi.org/10.1016/j.gloplacha.2012.10.014

[31] Yue, S., Pilon, P., Phinney, B. and Cavadias, G. (2002) The Influence of Autocorrelation on the Ability to Detect Trend in Hydrological Series. Hydrological Processes, 16, 1807-1829. https://doi.org/10.1002/hyp.1095

[32] Akinsanola, A.A. and Ogunjobi, K.O. (2017) Recent Homogeneity Analysis and Long-Term Spatio-Temporal Rainfall Trends in Nigeria. Theoretical and Applied Climatology, 128, 275-289. https://doi.org/10.1007/s00704-015-1701-x

[33] Kisi, O. (2015) An Innovative Method for Trend Analysis of Monthly Pan Evaporations. Journal of Hydrology, 527, 1123-1129. https://doi.org/10.1016/j.jhydrol.2015.06.009

[34] Wu, H. and Qian, H. (2017) Innovative Trend Analysis of Annual and Seasonal Rainfall and Extreme Values in Shaanxi, China, since the 1950s. International Journal of Climatology, 37, 2582-2592. https://doi.org/10.1002/joc.4866

[35] Batima, P., Natsagdorj, L., Gombluudev, P. and Erdenetsetseg, B. (2005) Observed Climate Change in Mongolia. AIACC Working Paper No. 12, 1-26.

[36] Booij, M.J. (2005) Impact of Climate Change on River Flooding Assessed with Dif- 
ferent Spatial Model Resolutions. Journal of Hydrology, 303, 176-198.

https://doi.org/10.1016/j.jhydrol.2004.07.013

[37] Li, Z., Liu, W.-Z., Zhang, X.-C. and Zheng, F.-L. (2009) Impacts of Land Use Change and Climate Variability on Hydrology in an Agricultural Catchment on the Loess Plateau of China. Journal of Hydrology, 377, 35-42.

https://doi.org/10.1016/j.jhydrol.2009.08.007

[38] Li, Y., Chang, J., Wang, Y., Jin, W. and Guo, A. (2016) Spatiotemporal Impacts of Climate, Land Cover Change and Direct Human Activities on Runoff Variations in the Wei River Basin, China. Water, 8, 220. https://doi.org/10.3390/w8060220

[39] Wang, H., Zhang, M., Zhu, H., Dang, X., Yang, Z. and Yin, L. (2012) Hydro-Climatic Trends in the Last 50 Years in the Lower Reach of the Shiyang River Basin, NW China. Catena, 95, 33-41. https://doi.org/10.1016/j.catena.2012.03.003

[40] Cheung, W.H., Senay, G.B. and Singh, A. (2008) Trends and Spatial Distribution of Annual and Seasonal Rainfall in Ethiopia. International Journal of Climatology, 28, 1723-1734. https://doi.org/10.1002/joc.1623 